\title{
THE RIGHT TO A PRE-DISMISSAL HEARING IN TERMS OF THE COMMON LAW: ARE THE CIVIL COURTS MISDIRECTED?
}

\author{
Stefan van Eck \\ $B L C L L B$ LLD \\ Professor of Law \\ University of Pretoria
}

SUMMARY

This article explores the overlap between the unlawful termination of a contract of employment and the unfair dismissal of an employee. The Supreme Court of Appeal has in a sequence of cases developed the common-law contract of employment to include the implied right to a pre-dismissal hearing. Owing to the fact that labour legislation already regulates unfair dismissal law, this in effect creates a dual system of dispute resolution in relation to the termination of contracts of employment. The focus of this contribution is on the factors that allure dismissed employees to the civil courts and it highlights the problems that are associated with the overlap of the High Court's and the Labour Court's jurisdictions. Future developments are traversed and the Constitutional Court is called upon to bring an end to the development of parallel dispute resolution systems in respect of dismissal disputes.

\section{INTRODUCTION}

The rights and duties of employers and employees are regulated by multiple sources of law. In the South African context, it comprises a complex body of principles ${ }^{1}$ drawn from quarters which include international law, ${ }^{2}$ an overarching Constitution, ${ }^{3}$ the common-law contract of employment, delict, administrative law and a network of labour statutes. Despite its varied foundations, labour law has increasingly claimed existence as an

In Transnet Ltd v Chirwa (2006) 27 ILJ 2294 (SCA) par 33 the court referred to the overlap of administrative law, the common law and labour law as a "mystifying complexity". See also Van Eck "Labour Dispute Resolution in the Public Service: The Mystifying Complexity Continues" (2007) 28 ILJ 793.

2 South Africa is a member of the International Labour Organisation and has adopted a number of this organisation's key conventions.

3 The Constitution of the Republic of South Africa, 1996. 
independent discipline since labour law reforms in the $1980 \mathrm{~s}^{4}$ and the subject is currently included in the syllabi of most, if not all, LLB degrees being taught at tertiary institutions.

Employer-employee relations were historically primarily regulated by the principles derived from the law of contract. ${ }^{5}$ The requirements for such contracts to have binding effect, rules in respect of the breach of such agreements and remedies were all regulated by common-law principles. A jurisdiction based on fairness, which includes the right to a pre-dismissal hearing, was not recognised under the common law. ${ }^{6}$ However, all of this changed with the enactment of labour legislation which firmly entrenches the notion of fairness into the employment relationship.

In South Africa employees' rights are significantly enhanced by the Constitution $^{7}$ and labour legislation. The Constitution contains core workers' rights, which are given effect to in labour laws such as the Labour Relations Act (the "LRA"), the Basic Conditions of Employment Act ${ }^{9}$ and the Employment Equity Act. ${ }^{10}$ Policymakers drew heavily on International Labour Organisation (the "ILO") Convention 158, which regulates termination of employment at the initiative of the employer, when they fashioned Chapter VIII of the LRA. Under the right not to be unfairly dismissed, the onus of proving fair reasons and procedures, have been shifted to the employer. ${ }^{11}$ Added to this, the LRA established a specialised dispute resolution framework, which includes the Commission for Conciliation, Mediation and Arbitration (the "CCMA"), the Labour Court and Labour Appeal Court, with the view of giving expeditious and affordable finality to labour disputes. The LRA also contains tailor-made remedies for victims of unfair dismissals and unfair labour practices. Whereas the common law does not recognise a damages claim for want of a disciplinary hearing, ${ }^{12}$ and specific performance is the exception rather than the rule in respect of wrongful dismissal, ${ }^{13}$ the LRA has elevated reinstatement to the primary remedy and is combined with capped compensation for unfair dismissal. ${ }^{14}$

4 The National Party government established the Wiehahn Commission in 1977, which published recommendations in 1979 that fundamentally changed labour laws in the country. The former Industrial Court was established in 1980 and can be seen as the start of South Africa's modern era labour law.

5 See Brassey, Cameron, Cheadle and Olivier The New Labour Law (1987) 2-5 for a discussion of the shortcomings of the common-law contract of employment.

6 See, for instance, Mustapha v Receiver of Revenue 19583 SA 343 (A); and Gründling v Beyers 19672 SA 131 (W)

$S 23(1)$ of the Constitution.

66 of 1995.

75 of 1997.

55 of 1998.

S 188(1)(a)-(b), s 192 and Schedule 8 of the LRA, the Code of Good Practice: Dismissal.

Brassey et al 4 .

See Schierhout v Minister of Justice 1926 AD 99; and National Union of Textile Workers $v$ Stag Packings (Pty) Ltd (1982) 3 ILJ 285 (T) 292E.

$14 \mathrm{~S} 193$ and 194 of the LRA. 
After the enactment of the Constitution and the LRA around 1996, most dismissed employees appeared to prefer to rely on their statutory labour rights and remedies and enforced these rights through the CCMA and the Labour Court. ${ }^{15}$ One might have assumed that common-law principles in respect of the termination of contracts of employment were replaced by corresponding provisions contained in labour legislation. ${ }^{16}$ This, however, does not seem to be the case. The Supreme Court of Appeal has now confirmed that the common-law contract of employment has been developed to include the right not to be unfairly dismissed. ${ }^{17}$ Therefore, despite the fact that the LRA regulates unfair dismissal law, the civil courts may be approached to determine disputes about the termination of contracts of employment on common-law principles.

This contribution places the mentioned developments under the spotlight, provides an overview of the cases that gave rise to this dual system, ${ }^{18}$ traverses the factors that allure employees to the High Court and identifies problems associated with this phenomenon. Arguments are also advanced which favour the position that the civil courts may be misdirected in developing the common law to include the right to a pre-dismissal hearing.

\section{OVERVIEW OF SERIES OF CASES}

After the enactment of the Constitution and the LRA, Fedlife Assurance Ltd $v$ Wolfaard $t^{19}$ was the first significant case where the overlap between the common law and unfair dismissal provisions was highlighted. In this instance, the employer prematurely terminated a fixed-term contract of employment on grounds of the redundancy of the employee. Despite the existence of the CCMA and the Labour Court, the dismissed employee claimed damages in the High Court based on the "unlawful" breach of contract. The question before the Supreme Court of Appeal was whether the enactment of the LRA, with its substantive rights for dismissed employees, has simultaneously deprived employees of their common law rights.

Nugent AJA held that this is not the case and that existing common-law remedies have not been eliminated. ${ }^{20}$ The court held that the labelling of a dispute is of prime importance in determining whether the High Court has

15 Le Roux and Mischke "Constitutional and Common Law Remedies" 2007 16(11) CLL 111.

16 Van Niekerk, Christianson, McGregor, Smit and Van Eck Law@work (2008) 83. Mischke "Contractually Bound: Fairness, Dismissal and Contractual Terms" 2004 13(9) CLL 81 states that "[m]uch like the proverbial bad penny, the contract of employment keeps coming back (not that it really went away) - it may be eclipsed by labour legislation and considerations of fairness, but it retains its fundamental role of establishing the employment relationship".

17 See the cases discussed below.

18 Pretorius and Myburg "A Dual System of Dismissal Law: Comment on Boxer Superstores Mthatha \& Another v Mbenya (2007) 28 ILJ 2290 (SCA)" 200728 ILJ 2172.

19 [2001] 12 BLLR 1301 (SCA).

20 Fedlife Assurance Ltd $v$ Wolfaardt supra 1305 par 14 
jurisdiction to entertain such a dispute. Provided that the challenge is based on the "unlawful" breach of the contract of employment, rather than the "unfair" termination thereof, the High Court retains jurisdiction to consider the dispute. ${ }^{21}$ Although the question about the right to pre-dismissal procedures was not directly raised, Nugent AJA opined that the constitutional right to fair labour practices" ${ }^{22}$ may have "imported into the common-law employment relationship" the right not to be unfairly dismissed. ${ }^{23}$ In his minority judgment, Froneman AJA accepted the argument that the right not to be unfairly dismissed is a wider concept than the one based on unlawfulness. The first notion, he said, in essence encompasses the second. Because the LRA regulates the right not to be unfairly dismissed, he concluded that the High Court should abstain from entertaining such disputes and rather leave such matters to the specialist labour courts that were established for this purpose. $^{24}$

In a subsequent Supreme Court of Appeal judgment, Denel $v$ Vorster ${ }^{25}$ an employee based a claim on the unlawful termination of a contract of employment on grounds that the employer had failed to follow its contractually agreed upon internal disciplinary procedures to the letter. The employer argued that it had conducted a hearing and that it had complied with the broad notions of fairness imposed by section 23 of the Constitution. Nugent JA, this time on behalf of a unanimous bench, rejected the employer's argument and held that the employer's non-compliance with the rather detailed disciplinary code constituted breach of contract. ${ }^{26}$ With reference to the Wolfaardt case, the court held that the Constitution's influence in introducing fairness into the employment relationship does not deprive contractual terms of their binding effect. ${ }^{27}$ The court was requested to make a finding on the merits of the case only and, unfortunately, the appropriate remedy was not dealt with in much detail. The court did, however, allude to the fact that the basis for determining contractual damages is whether the prejudiced person's position would have been any different if a proper disciplinary hearing had taken place. ${ }^{28}$ This left the

21 In Fedlife Assurance Ltd $v$ Wolfaardt supra 1309 par 27 the court held that "[w]here ... the subject in dispute is the lawfulness of the dismissal, then the fact that it may also be, and probably is, unfair, is quite coincidental for that is not what the employee's complaint is about".

22 S 23(1) of the Constitution.

23 Fedlife Assurance Ltd v Wolfaardt supra 1305 par 14. See also Key Delta v Marriner [1998] 6 BLLR $647(\mathrm{E})$, where the High Court suggested that the law might have developed to the point where a pre-dismissal hearing could be implied into a contract of employment.

24 Fedlife Assurance Ltd $v$ Wolfaardt supra 1313 par 42-44.

25 [2005] 4 BLLR 313 (SCA).

26 This case illustrates how different approaches can develop in different courts. In Highveld District Council v CCMA [2002] 12 BLLR 1158 (LAC) the Labour Appeal Court held that even if an employer deviates from a disciplinary code it could still constitute a fair procedure if the actual procedure followed can still be deemed to be fair.

27 Denel $v$ Vorster supra 318 par 16.

28 Denel $v$ Vorster supra 319 par 17. The court referred to Trotman v Edwick 19511 SA 443 (A). 
question unanswered regarding the value, if any, that could be placed on the loss suffered due to an insufficient hearing. Also unanswered, was the issue whether the right not to be unfairly dismissed has become an implied term of the contract of employment.

Last-mentioned puzzle was answered in the affirmative in the year 2007 in a pair of Supreme Court of Appeal judgments, Old Mutual Life Assurance Co $S A$ Ltd $v$ Gumb ${ }^{29}$ and Boxer Superstores Mthatha $v$ Mbenya, ${ }^{30} 6$ years after the question had been raised in the Wolfaardt case. In Gumbi, the employee challenged the unlawful breach of his contract of employment on grounds that his employer had conducted a disciplinary enquiry in his absence. Jafta JA held that, pursuant to the enactment of the Constitution and the adoption into our law of ILO Conventions, the right to a pre-dismissal hearing is "well recognised" in our law. ${ }^{31}$ The court also made the obiter observation that the entitlement to a pre-dismissal hearing is now incorporated into the commonlaw contract of employment. ${ }^{32}$ Despite this, the court did not assist the employee in this instance. The court held that the right to a hearing is not absolute and only imposes on the employer an obligation to offer the employee an opportunity to be heard. Procedural fairness cannot be challenged if, as in this case, the employee and his representative were to blame for his absence from the hearing.

The Boxer Superstores case followed closely on the Gumbi decision. Here, the claimant employee pleaded that the termination of her contract of employment constituted breach of contract on grounds that her dismissal was substantively unfair and that it was also procedurally unfair for want of an adequate hearing. The applicant launched an application in the High Court requesting the decision of the employer to be set aside and for an order to declare "unlawful" the pre-dismissal hearing and to reinstate her with back pay. The employer raised a point of law that the High Court lacked jurisdiction to entertain the application. The argument was dismissed, and it was against this decision that an appeal was lodged with the Supreme Court of Appeal. With reference to the Gumbi case, Cameron JA formulated the position as follows:

"This case pushes the boundary a little further ... This Court has recently held that the common-law contract of employment has been developed in accordance with the Constitution to include the right to a pre-dismissal hearing (Old Mutual Life Assurance Co SA Ltd v Gumbi).

[2007] 8 BLLR 699 (SCA).

30 [2007] 8 BLLR 693 (SCA).

31 Old Mutual Life Assurance Co SA Ltd v Gumbi supra 701 par 5-6. The court remarked that "[i]n recognising this right our law is consistent with international law relating to predismissal hearings as set out in Article 7 of the International Labour Organisation (the ILO) Convention on Termination of Employment 158 of 1982".

32 Old Mutual Life Assurance Co SA Ltd v Gumbi supra 701 par 5.

33 Boxer Superstores Mthatha $v$ Mbenya supra 696 par 6. 
Counsel for the employer argued that although the employee was careful to base her claim on "the lawfulness of her dismissal, in substance, her complaint was about its fairness". ${ }^{34}$ The court found that, even though there may be some merit in this argument, jurisdictional determinations nevertheless often involve questions of form and that in this instance the claimant was careful to rely solely on contractual unlawfulness, which gives the High Court the jurisdiction to entertain the dispute. Cameron JA did, however, voice a note of caution when he suggested that common-law remedies may not be as favourable as the statutory remedies that include reinstatement and compensation. ${ }^{35} \mathrm{He}$ stated that "the ordinary courts should be careful in employment-related matters not to usurp the Labour Courts' remedial powers". ${ }^{36}$ The court concluded that even though the factual allegations before the High Court may later be found to be correct, the employee may ultimately only be entitled to have the employer's decision to be set aside.

Turning for the moment to the position in the United Kingdom, the House of Lords has rejected arguments in favour of granting common-law damages in circumstances where labour legislation provides for the payment of compensation for an unfair dismissal. In Eastwood v Magnox Electric PIc, ${ }^{37}$ it was held that a:

"common law obligation having the effect that an employer will not dismiss an employee in an unfair way would be much more than a major development of the common law of this country. Crucially, it would cover the same ground as the statutory right not to be dismissed unfairly, and it would do so in a manner inconsistent with the statutory provisions. In the statutory code Parliament has addressed the highly sensitive and controversial issue of what compensation should be paid to employees who are dismissed unfairly ... In fixing these limits on the amount of compensatory awards Parliament has expressed its view on how the interests of employers and employees, and the social and economic interests of the country as a whole, are best balanced in cases of unfair dismissals."

\section{ALLURE TO THE CIVIL COURTS AND POTENTIAL PROBLEMS}

It is common cause that CCMA and Labour Court processes were designed to assist amongst others dismissed employees. Generally, the procedures

34 Boxer Superstores Mthatha v Mbenya supra 697 par 11.

$35 \mathrm{~S} 193$ and 194 of the LRA.

36 Boxer Superstores Mthatha v Mbenya supra 696 par 9 . At this stage it is uncertain whether the maximum damages to which an employee is entitled equals remuneration for the contractual notice period. In Harper $v$ Morgan Guarantee Trust Co of New York, Johannesburg 20043 SA 253 (W) $258 \mathrm{H}-\mathrm{I}$ the court held: "There is obvious logic for limiting the damages claim to the equivalent of earnings in the permissible notice period."

37 [2004] UK HL 35 par 12-13. Here, the court followed Johnson v Unisys Ltd [2001] UK HL 31. 
are expeditious, less legalistic and affordable.$^{38}$ What, then, would prompt a potential litigant to opt for the civil courts while the advantages of relying on the specialist institutions are well known? It is submitted that two main factors may encourage disgruntled employees to elect the route of the civil courts. First, unfair dismissal disputes must be lodged within 30 days of the date of dismissal (and unfair labour practice disputes within 90 days), ${ }^{39}$ and secondly, as trade-off for expeditiousness, the LRA imposes a cap of 12 months' remuneration on compensation for unfair dismissal. ${ }^{40}$ In terms of the Prescription Act, ${ }^{41}$ civil claims generally prescribe three years after the date of the incident that gives rise to a claim and there is no cap on common-law damages in respect of breach of contract beyond the fact that actual loss must be proved. ${ }^{42}$ As alluded to in Denel $v$ Vorster and Boxer Super Stores, last-mentioned common-law remedy may in itself be problematic to prove.

There are a number of obvious reasons why more time may be to the advantage of a litigating party. The dismissed employee may not have been aware of the relatively short 30 day period or of the fact that his or her employee rights had been transgressed. And, there are those instances where either the dismissed employee or his or her legal representative has run out of time due to their own carelessness. More speculative reasons may include: a perception on the part of the dismissed employee's legal representative that High Court processes are more efficient than those encountered at the CCMA; and the prospective litigant may have approached a legal representative who feels more at home to litigate in the High Court rather than in the institutions established by the LRA.

Pretorius and Myburgh $^{43}$ raise a number of valid problems and uncertainties regarding the dual roles of the High Court and the dispute resolution institutions established by the LRA. Will the High Court be prepared to accept deviations from exacting court-like disciplinary enquiries such as were accepted in the illuminating Labour Court case Avril Elizabeth Home for the Mentally Handicapped v CCMA? ${ }^{44}$ When the High Court evaluates whether an employer has established misconduct, will the court be willing to deviate from the strict rules of evidence, such as the labour courts have been willing to do $?^{45}$ Will the High Court be prepared to deviate from the strict letter of disciplinary codes in favour of the overall spirit of audi

38 Van Eck "The Constitutionalisation of Labour Law: No Place for a Superior Labour Appeal Court in Labour Matters (Part 1)" 2005 Obiter 26(3) 549.

39 See $\mathrm{s}$ 191(1)(b) of the LRA.

40 S 194(1) of the LRA. In respect of automatic unfair dismissals, s 194(4) sets the cap at 24 months' remuneration.

41 S 11(d) of the Prescription Act 68 of 1969.

42 Claimants with more than 12 months remaining on the contract may find a contractual claim attractive compared to the capped compensation. See Buthelezi v Municipal Demarcation Board [2005] 2 BLLR 115 (LAC).

43200728 ILJ $21722174-2175$.

44200627 ILJ 1644 (LC).

45 See Le Monde Luggage CC t/a Packwells Petje v Dunn NO 200728 ILJ 2238 (LAC). 
alteram partem or will the courts maintain the contractual approach as adopted in Denel $v$ Vorster? ${ }^{46}$ And, will the High Court also apply the provisions of the LRA in respect of constructive dismissal ${ }^{47}$ cases involving poor work performance, incapacity due to ill-health or injury and operational requirements? The authors also identify the intriguing possibility that it may be possible to appeal from the High Court against a decision about unlawful dismissal but that it is only possible to take a CCMA award on review. Added to this, the untenable possibility arises for an employee to challenge the fairness of dismissal in the CCMA, and simultaneously or after losing the matter, to dispute the unlawful breach of the contract of employment in the High Court.

Apart from these practical issues, an undesirable policy-related "classbased" system of dispute resolution could develop. ${ }^{48}$ Whereas the more well-off (who can afford legal representation) may favour the path of the civil courts, economic realities may force the underprivileged to utilise the CCMA and bargaining council structures.

\section{ROOTS OF THE DUAL SYSTEM}

There are at least two main underlying causes for the development of the dual dispute resolution system. The first flows from the interpretation of the Constitution, and the second lies within the wording of the LRA, which attempts to clothe the Labour Court with exclusive jurisdiction. In the Gumbi case, the court held that the common law recognises both the co-ordinate rights of "lawfulness" and "fairness" and that the Constitution imposes an imperative on the courts to harmonize the common law into the Bill of Rights. ${ }^{49}$ The court referred to section 39(2) that states that:

"[w]hen interpreting any legislation, and when developing the common law or customary law, every court, tribunal or forum must promote the spirit, purport and objects of the Bill of Rights" (own emphasis).

Although the court did not refer to section 8(3) of the Constitution, the picture is more complete taking into account that it states that:

"When applying the provisions of the Bill of Rights to a natural or juristic person .... a court -

(a) in order to give effect to a right in the Bill, must apply, or if necessary develop, the common law to the extent that legislation does not give effect to that right" (own emphasis).

46 As discussed above.

7 In Murray v Minister of Defence [2008] 6 BLLR 513 (SCA) the Supreme Count of Appeal has done just that in applying principles developed by the labour courts in respect of soldiers who are excluded from the ambit of the LRA.

48 Du Toit "Through the Looking-Glass" Paper at SASLAW Annual Conference, October 2007, Cape Town, 3.

49 Old Mutual Life Assurance Co SA Ltd v Gumbi supra 701 par 5. 
Sound arguments have been raised why the court in Gumbi may have been misguided in its approach. ${ }^{50}$ Neither of the sections establishes an imperative to develop the common law in each instance. Section 39(2) does not state that every court and tribunal "must" interpret legislation and "must" develop the common law in each case before it. It states that "when" the common law is being developed it "must" promote the spirit of the common law. Section 8(3) gives some indication about when this constitutional imperative is activated. This is, namely "if necessary" to do so and then only "to the extent that legislation does not give effect to the right". ${ }^{51}$ It is submitted that the LRA was enacted with that exact purpose, namely to give effect to the constitutional right to fair labour practices and in particular the right not to be unfairly dismissed. It follows that it was not necessary to develop the common law as it had been done in Gumbi and Boxer Superstores. As pointed out in the minority judgment of Wolfaardt, and partly so in the Boxer Superstores case, unfairness is a wide enough concept to cover unlawful termination, and unfair dismissal is already addressed in the LRA.

Still with the issue of constitutional interpretation, Cheadle refers to section 173 of the Constitution, which provides further guidance under which circumstances the common law should be developed. The section recognises the High Court's inherent power to arrange its own processes and to develop the common law in this regard by "taking into account the interests of justice". In Carmichele v Minister of Safety and Security ${ }^{52}$ the Constitutional Court held that judges should be mindful of the fact that the principal driver for law reform and the development of the common law should be the legislature and not the judiciary. The legislature has already implemented dispute resolution structures for the resolution of dismissal cases and it is doubtful that it is in the interests of justice to develop an alternative contractual remedy in the civil courts which operates parallel to the CCMA and the Labour Courts.

Account should also be taken of the fact that the Constitutional Court has on a number of occasions confirmed that where legislation is enacted to give effect to a constitutional principle, a litigant may not bypass that legislation and rely directly on the Constitution without challenging that the legislation falls short of meeting the constitutional standard. ${ }^{53}$ In not one of the cases discussed above had the LRA been subjected to constitutional challenge that it does not provide sufficient protection to employees against unfair dismissal.

50 Cheadle "Labour Law and the Constitution" Paper at SASLAW Conference, October 2007, Cape Town, 3-6.

51 Cheadle 6

5220014 SA 938 (CC).

53 NAPTOSA v Minister of Education, Western Cape 20012 SA 112 (C); Minister of Health NO v New Clicks SA(Pty) Ltd 20062 SA 311 (CC); and SA National Defence Union v Minister of Defence [2007] 9 BLLR 785 (CC) par 53-56. 
Turning to the wording of the LRA, section 157 of the LRA attempts to draw the dividing line between the jurisdictions of the High Court and the Labour Court. The architects of the LRA were acutely aware of the problems that were experienced with the competing jurisdictions of the former Industrial Court and Supreme Court (now the High Court) and they aimed to avert "the overlapping and competing jurisdictions" 54 of the civil and labour courts. To this end, the LRA has as one of its stated objectives "to promote ... the effective resolution of labour disputes". ${ }^{55}$ However, in what may arguably be described as one of the most significant shortcomings of the LRA in general, is the fact that section 157 of the LRA was not able to avert uncertainty about jurisdictional matters.

Section 157(1) confers exclusive jurisdiction on the Labour Court in respect of "all matters that elsewhere in this Act [the LRA] or in terms of any other law are to be determined by the Labour Court". Section 157(2) provides that "the Labour Court has concurrent jurisdiction with the High Court" in respect of any alleged violation of the rights entrenched in the Constitution.

Both sections 157(1) and (2) include the potential for overlapping jurisdiction. In 2001 Zondo JP in Langeveldt v Vryburg Transitional Local Council $^{56}$ opined that a state of affairs had been established that "provides fertile ground for the unacceptable practice of forum-shopping". ${ }^{57}$ Owing to the fact that an aspect like "unlawful breach" is not specifically mentioned in the LRA, the civil courts have found that it does not fall under "all matters" that arise from the LRA.

Owing to the wide scope of constitutional rights, such as the right to fair labour practices, most if not all aspects of the LRA could be classified as alleged violations of rights contained in the Constitution, which could bring section 157(2) into play. The Constitutional Court in Fredericks v MEC for Education and Training, Eastern Cape ${ }^{58}$ has confirmed that as long as a litigant bases a claim on the breach of a constitutional right, the matter is a "constitutional matter" about which the High Court and Labour Court has concurrent jurisdiction.

54 Explanatory Memorandum to the Draft Negotiating Document in the Form of a Labour Relations Bill, Government Gazette 16259 of 10 February 1995 147-148. See also Van Eck and Vettori "Does the High Court have Concurrent Jurisdiction with the Labour Court to Hear Unfair Dismissal Disputes? - Runeli v Minister of Home Affairs 2000 ILJ 910 (Tk)" Obiter 2000490.

55 S 1 (d)(iv) of the LRA.

56 [2001] 5 BLLR 501 (LAC) par 55; and 524 par 69 Zondo JP said that "the problems I have highlighted need urgent attention by the government and all relevant stakeholders".

57 Langeveldt $v$ Vryburg Transitional Local Council 523 par 64.

58 [2002] 2 BLLR 119 (CC). 


\section{$5 \quad$ WHAT DOES THE FUTURE HOLD?}

Mindful of the untenable situation prevailing regarding the overlapping jurisdictions of the Labour and High Courts, the Superior Courts Bill ${ }^{59}$ was published for discussion in August 2003. ${ }^{60}$ The Bill proposes that the Labour Court and Labour Appeal Court will be abolished and that all labour law matters will be heard by the High Court. Judges of the High Court who have expertise in labour law will hear labour matters. Appeals in these matters will be heard by the Supreme Court of Appeal. Five years since the publication of the Bill it seems that the debate about these proposed changes has lost momentum and has been placed on hold for the moment. ${ }^{61}$

However, in what may yet become a defining moment in the tug-of-war between the competing positions of the Labour Court and the High Court, the Constitutional Court in Chirwa $v$ Transnet $L t d^{62}$ has recently once again had the opportunity to interpret sections 157(1) and (2) of the LRA. Although the matter concerned the overlap of administrative and labour law principles - rather than the interaction between the law of contract and LRA principles it may yet result in developments in favour of exclusive jurisdiction for the Labour Court in the interim period while policy makers have not finalised this aspect.

In what is important for purposes of this contribution, the Chirwa decision called into question the approach adopted by Gumbi and Boxer Superstores. Skweyiya and Ngcobo JJ, writing separate decisions for the majority of the court, held that the LRA envisaged the establishment of a comprehensive system of dispute resolution and that the High Court does not enjoy concurrent jurisdiction with the Labour Court in the labour sphere in matters already covered by the LRA. The court noted that in Gumbi and Boxer Super Stores the Supreme Court of Appeal relied on form (and the manner in which the dispute was labelled) rather than basing their decisions on the substance of the matter. Ngcobo observed that this would leave scope for an astute litigant to bypass the LRA's specialist fora and to "rob the Labour Courts of their need to exist". ${ }^{63}$ Section 157(1) of the LRA was aimed at

59 Superior Courts Bill [B-2003].

60 For a discussion of the Superior Courts Bill see Waglay "The Proposed Re-organisation of the Labour Court and the Labour Appeal Court" 200324 ILJ 1223; Benjamin "A Termination for Operational Requirements? Some Thoughts on the End of the Labour Court" 200324 ILJ 1869; and Strydom "Changing the Labour Court: The Superior Courts Bill 2003" 2003 13(3) CLL 22.

61 It is submitted that even if these proposals were to be implemented, the overlap between contractual claims and those in relation to unfair dismissal will not disappear. The CCMA will retain its function of considering the bulk of unfair dismissal claims and in those instances where litigants are out of time or where they feel that they would gain some remedial advantage based on the contract of employment in the High Court they will continue to follow that route.

62 [2008] 2 BLLR 97 (CC).

63 Chirwa $v$ Transnet Ltd supra 126 par 95. 
entrusting the specialist forums with the primary interpretation and application of the LRA's provisions. Section 157(2) was included to extend the jurisdiction of the Labour Court and not to confer concurrent jurisdiction to the High Court. The court held that the main purpose of the section is:

"not so much to confer jurisdiction to the High Court to deal with labour and employment related disputes, but rather to empower the Labour Court to deal with causes of action that are founded on the provisions of the Bill of Rights but which arise from employment and Labour Relations".

At face value it seems that the Chirwa and Fredericks cases handed down by the Constitutional Court contradict each other ${ }^{65}$ However, having taken account of the disparities between the cases, the Supreme Court of Appeal in Makambi v MEC, Department of Education, Eastern Cape ${ }^{66}$ recently held that it was bound to follow Chirwa, which was decided at a later stage than the Fredericks decision.

\section{CONCLUDING REMARKS}

The Gumbi and Boxer Superstores decisions are clear indicators that the Supreme Court of Appeal is eager to retain its jurisdiction to entertain disputes regarding the unlawful termination of contracts of employment. Unless the Constitutional Court overturns this position, or the legislature changes the current impasse, every employee now has the common-law right to a pre-dismissal hearing in terms of the contract of employment.

It is in my view disappointing that the Supreme Court of Appeal in this country, in stark contrast to the position adopted by the House of Lords in Great Britain, has not been willing to abdicate a portion of its inherent jurisdiction to finalise disputes about the termination of contracts of employment - this despite the fact that it is already regulated by policies fashioned by the legislature after consultation with business and organised labour. Such an approach would have circumvented numerous uncertainties and problems that have now been created by the parallel systems of dispute resolution regarding the termination of contracts of employment.

It is submitted that, if the position as formulated by the Gumbi and Boxer Super Stores cases remains unchanged, employees may yet find that it translates into hollow victory. Although a dismissed employee may attain partial success on the merits of unlawful termination in the High Court, the claimant may still be faced with a situation where the court is not eager to usurp the remedial powers of the Labour Court. As suggested in Boxer

64 Chirwa $v$ Transnet Ltd supra 135 par 120.

65 In Nakin v MEC, Department of Education, Eastern Cape Province [2008] 5 BLLR 489 (Ck) it was held that Chirwa was in conflict with Fredericks, and that as lower court it could elect which decision it preferred to follow. 66 [2008] 8 BLLR 711 (SCA). See also the full bensch decision of the Bisho High Court,
Nonzamo Cleaning Services Cooperative v Appie [2008] 9901 (Ck), where the Chirwa judgment rather than the Fredericks decision was followed. 
Super Stores, such matters may in future merely be set aside and referred back to the workplace for a re-hearing to take place. Dismissed employees may also find themselves caught up in costly litigation during a phase when appropriate common-law remedies are still being developed under the common law.

The Constitutional Court has shown a willingness to protect the exclusive jurisdiction of the Labour Court in respect of the overlap between administrative law and labour law principles. It is suggested that it would be a logical development for the same court to bring the dual system of dispute resolution in respect of the unlawful versus unfair termination of contracts of employment to its logical conclusion in the same fashion. 